\title{
The mechanism for value formation in a trading enterprise
}

\author{
Oksana Pirogova ${ }^{1, *}$ and Marina Makarevich ${ }^{1}$ \\ ${ }^{1}$ Peter the Great St.Petersburg Polytechnic University, Polytechnicheskaya, 29, St. Petersburg, \\ 195251, Russia
}

\begin{abstract}
Currently, one of the problems in managing the development of trade enterprises is the problem of choosing the type of value and management of this value. This problem can be solved on the basis of the concept of value-based management (VBM). The concept is based on the value of the enterprise, which, in the form of a quantitative integrated assessment, reflects the efficiency of the operation and the prospects for the development of the enterprise, balancing in one measure such important economic categories of microeconomics as profitability, risk and growth rates. The article considers the types of value used in the valuation of trading enterprises and shows that the fundamental value can be used in managing the development of a trading enterprise. The article considers the components of the fundamental value, which include the balance component, the operating component, the investment component, and the component of dynamic flexibility. The fundamental value covers all levels of management of a trading enterprise, both strategic and tactical. As it allows building a developed system of indicators, managers will be made it possible to make well-founded management decisions and contribute to the main task of increasing the value of a trading enterprise. The offered approach allows linking the components of the fundamental value of a trading enterprise with the levels of management of the enterprise and the forms of activity of a trading enterprise.
\end{abstract}

\section{Introduction}

The basis of the commodity distribution system of any state is the trade sector. In many countries of the world, trade occupies one of the leading positions [9]. The Russian Federation is not an exception in this respect either. The trade branch of Russia is one of the leading branches of the national economy. The modern trade branch of Russia is one of the most stable branches of the national economy. This is evidenced by the comparative dynamics of the gross domestic product (GDP) and the retail trade turnover of the Russian Federation in recent years (Fig. 1).

A comparative analysis of the growth rates of GDP and the turnover of retail trade over the past ten years suggests that the trade sector is characterized by relatively higher and stable growth rates compared to GDP. Trade is characterized by high levels of growth of gross

\footnotetext{
*Corresponding author: kafedra17@rambler.ru
} 
added value in comparison with other branches of the economy [1, 2]. Prospects for the development of the trade sector pose serious development challenges for each individual commercial enterprise. After all, it will depend on this, how the trade industry will develop. At the same time, the achievement of these indicators is impossible without the introduction of modern management methods into the practice of management [4, 20].

One of the productive concepts of management at the present stage of management development is the concept of value-based management (VBM) $[3,8,10]$. This concept assumes that an enterprise as an open socioeconomic system in the process of its growth and development must strive to maximize its value [10 - 12].

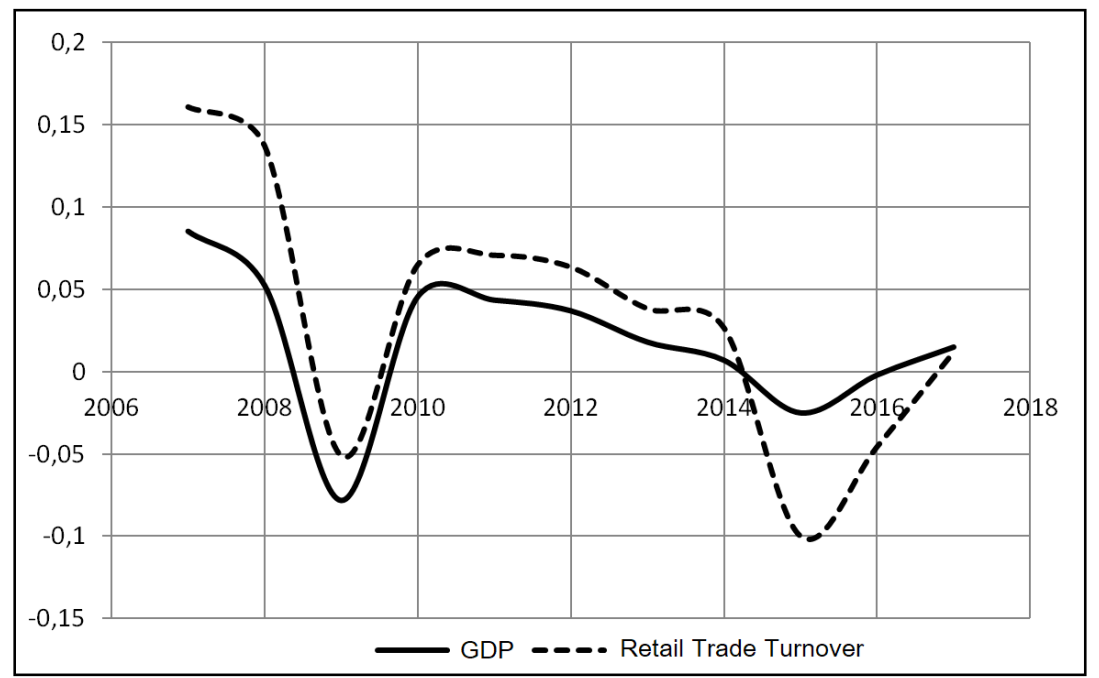

Fig. 1. Comparative analysis of the growth rates of GDP and retail trade turnover in the Russian Federation.

Despite a number of obvious advantages, the introduction of the value concept into the activities of domestic trade enterprises, meets serious difficulties, which include $[10,11]$ : - the currently developed financial and economic models and methodological approaches are designed primarily for large trading enterprises, but for small and medium-sized enterprises this concept remains inapplicable;

- a great variety of indicators of value or its growth for an enterprise make it difficult to choose the most appropriate one, and also complicates the possibility of comparing results due to their heterogeneity in economic content and dimension;

- there are significant difficulties in the decomposition of the integral indicator of value at the operational level and the decomposition of strategic objectives into the area of operational management of the enterprise.

In addition to the organizational problems of implementation, issues related to the choice of the type of value that is built into the management loop, as well as the choice of approaches to calculate this cost, are of no less importance [10 - 12].

\section{The problems of choosing the value type}

The complexity of choosing the type of value used to form a management system for the development of trade enterprises is determined [11]:

- the ambiguity of the position of specialists in determining the value;

- the need to integrate the assessments obtained on the basis of different approaches, taking into account their specific features and internal content; 
- a wide variety of tasks and objectives of valuation in the construction of enterprise development management system;

- the need to take into account the specifics of the Russian economy.

When analyzing the types of value, an important point is the consideration of the types of value presented in official documents and recognized universally. The definition of value and its types is introduced by federal standards of assessment. In accordance with the federal standard for the assessment of FSO-1 [13], value is the estimated measure of the price at the valuation date in accordance with the selected type of value. Despite the fact that in the federal standard for the assessment of FSO-2 [14] it is stated that the value, as the final value and the result of the evaluation, can be used including for management purposes - for making managerial decisions, the analysis of the types of value given in the standard shows that they do not fully comply with the tasks of managing the development of a trading enterprise. A brief description of the types of value introduced by FSO-2 is presented in Table 1.

Table 1. Values used in the FSO-2 assessment standards.

\begin{tabular}{|c|l|}
\hline $\begin{array}{c}\text { Types of value in } \\
\text { accordance with FSO -2 }\end{array}$ & \multicolumn{1}{c|}{ Characteristics of the type of value } \\
\hline Market value & $\begin{array}{l}\text { Determined if the object of valuation involves the execution of a } \\
\text { transaction or other action involving the alienation of the valuation } \\
\text { object }\end{array}$ \\
\hline Investment value & $\begin{array}{l}\text { The cost for a particular person or group of persons with investment } \\
\text { objectives established by the person or group of persons }\end{array}$ \\
\hline Liquidation value & $\begin{array}{l}\text { It assumes the account of the extraordinary circumstances compelling } \\
\text { to sell the object of valuation on conditions that do not correspond to } \\
\text { the market conditions of sale }\end{array}$ \\
\hline Cadastral value & $\begin{array}{l}\text { It is intended for taxation purposes, as well as other purposes } \\
\text { determined by law, and involves the implementation of market value } \\
\text { assessment by mass valuation methods }\end{array}$ \\
\hline
\end{tabular}

In general, we can state the fact that the types of valuation offered in domestic standards cannot be used to the full extent for their management purposes. Along with this, the use of these types of value is absolutely necessary in special cases arising in the course of the enterprise's activity and as a rule determined by law.

International valuation standards also offer several types of value. The main base is the market value, but the conditions in which it can be applied are very difficult to observe when assessing the value of an enterprise, which is primarily due to the complex multilateral concept of the enterprise as an economic object. It is important to note that in this case the concept of an enterprise is not reducible to the concept of a property complex. The nonmarket valuation of an enterprise's value in current international valuation standards is the effective value (Deprival Value or, sometimes, Optimal Deprival Value) [15].

In the economic literature in recent years, there have also appeared other types of value: market value; fair (reasonable market value); stakeholder value (value determined on behalf of interested parties); fundamental value. The offered types of value are intended directly for the assessment of companies or enterprises in the management of their activities.

Of all the considered types of value, only a large part answers the questions of value formation, but only the fundamental value answers the question of generating value at all levels of the enterprise's activity. Based on the data in Table 1, it can be concluded that it is necessary to use in the management of the development of trade enterprises types of value, based not on the external evaluation of the enterprise, but on the internal evaluation of the potential for value growth. Therefore, an important point in determining the value is to take into account the fundamental factors when creating it. To form a management system for the development of a trading enterprise, it is important to use a fundamental value, which is based on an analysis of the financial and operational indicators of the enterprise [17]. 
Table 2. Comparison of different types of value used for enterprise development management. [5 - 8].

\begin{tabular}{|c|l|l|}
\hline Benchmark & \multicolumn{1}{|c|}{ Economic Content } & \multicolumn{1}{c|}{ Objectivity } \\
\hline $\begin{array}{c}\text { Market } \\
\text { value }\end{array}$ & $\begin{array}{l}\text { The process of capitalization as an increase } \\
\text { in the market price }\end{array}$ & $\begin{array}{l}\text { Subject to the influence of } \\
\text { subjective and objective market } \\
\text { factors }\end{array}$ \\
\hline $\begin{array}{c}\text { Fair } \\
\text { value }\end{array}$ & $\begin{array}{l}\text { The price expressed in money or their } \\
\text { equivalents at which the property } \\
\text { (enterprise) would pass from hand to hand }\end{array}$ & $\begin{array}{l}\text { Subject to the influence of the } \\
\text { subjective views of the seller and } \\
\text { buyer }\end{array}$ \\
\hline $\begin{array}{c}\text { Stakeholder } \\
\text { value }\end{array}$ & $\begin{array}{l}\text { Discounted cash flow of all benefits to } \\
\text { financial and non-financial stakeholders } \\
\text { (stakeholders) of the enterprise }\end{array}$ & $\begin{array}{l}\text { The least objective, since the } \\
\text { benefits of stakeholders are } \\
\text { originally subjective }\end{array}$ \\
\hline $\begin{array}{c}\text { Investment } \\
\text { value }\end{array}$ & $\begin{array}{l}\text { Discounted cash flow of the benefits of a } \\
\text { particular investor from investing in an } \\
\text { enterprise }\end{array}$ & $\begin{array}{l}\text { Subject to the influence of } \\
\text { subjective market factors, as well as } \\
\text { the views of a particular investor }\end{array}$ \\
\hline $\begin{array}{c}\text { Fundamental } \\
\text { value }\end{array}$ & $\begin{array}{l}\text { The forecasted value of the enterprise, } \\
\text { based on the analysis of its financial and } \\
\text { operational indicators, as well as the current } \\
\text { state of the resource potential }\end{array}$ & $\begin{array}{l}\text { The most objective, because it takes } \\
\text { into account the impact of } \\
\text { significant factors of the enterprise }\end{array}$ \\
\hline
\end{tabular}

Thus, we can formulate the following basic signs of fundamental value [16]:

- the fundamental value should be applied, first of all, in the activities of enterprises (companies) in which the real creation of surplus value is carried out (the real sector);

- the valuation of the fundamental value should be carried out for the enterprise as acting, the sale of the enterprise in the near and medium term is not expected (in the case of the sale of the enterprise, other types of value should be applied);

- the fundamental value should reflect the current state of the assets of the enterprise, its ability to generate revenue not lower than the weighted average cost of capital;

- the fundamental value should reflect the state of the resource potential of the enterprise, as its ability to develop in alternative directions;

- the fundamental value should reflect the interests of the owner of the enterprise (obtaining a return on invested capital no lower than the market value for investments with a similar risk)

- a fundamental assessment of the value should be carried out taking into account the interests of the main financial stakeholders (creditors, investors), as well as non-financial stakeholders.

Based on the requirements to the fundamental value, it becomes obvious that it must have a complex internal structure that allows reflecting aspects of value creation in various areas of the enterprise's activities. A distinctive feature of the approaches developed to date to assess the value of an enterprise is one important drawback. The indicator offered for calculation is based on the main economic performance indicators - economic profit, or free cash flow. At the same time, it does not disclose internal mechanisms for creating value associated with cash flow generation within the enterprise, as well as changes in key performance indicators in the enterprise development process that are subject to significant transformation.

\section{Contours of creating a fundamental value}

To identify the internal structure of the contours of creating a fundamental value of an enterprise, it is advisable to consider the basic forms of the enterprise's activity. Here we can distinguish the following forms of activity [18]:

- production form of activity; 
- a reproductive form of activity, including ordinary and extended reproduction.

The production form of the enterprise's activity is aimed at the implementation of statutory activities and consists of the transformation of resources into products and services. Due to production activities, the enterprise meets the demand for goods and services. Reproduction, as a form of activity at the enterprise, is a process of maintaining, building up and modernizing the enterprise's potential to provide the production function, taking into account the changing external factors of the enterprise.

It is believed that these functions are implemented at three levels of enterprise management [19]:

- a tactical level that includes the processes of managing the current operational activities;

- a strategic level that includes the processes of managing the reproductive activity at the enterprise in support of production activities;

- institutional (superstrategic) level, which includes the processes of managing the reproduction of the potential of the enterprise reproductive base.

These levels of management make it possible to realize the most important function - the reproduction of capital.

Taking into account the presented features of cost management of enterprise development as a basic type of value, we are invited to consider the fundamental value, consisting of four main interacting terms:

- the book value of tangible and intangible assets;

- the operational value of the enterprise, as its ability to generate free cash flow, or economic profit (economic added value) in the time period of use of existing assets of the enterprise, which is a free cash flow discounted at the time of making the management decision, or a stream of economic profit (added value);

- the investment value of an enterprise as the ability to form and maintain the assets of an enterprise in the required state on the basis of transformation of investments in assets creating additional competitive advantages, representing net present value of the enterprise's ongoing and planned investment activity that solves the problems of ordinary and extended reproduction;

- the cost of dynamic flexibility of the enterprise, which consists in the ability to adequately change depending on changes in external conditions on the basis of the existing resource potential in a given direction with the aim of achieving a new state of the resource potential ensuring a positive composition and growth of the three previous components in the long term.

The offered model of fundamental value in connection with the forms of activity and management levels is conveniently represented in the form of the scheme shown in Fig.2

In our opinion, such a representation of fundamental value has a number of advantages.

First, the division of costs into levels allows us to build an expanded system of cost factors and to distinguish among them key indicators of effectiveness and efficiency. 
Components of the fundamental value of a trading enterprise

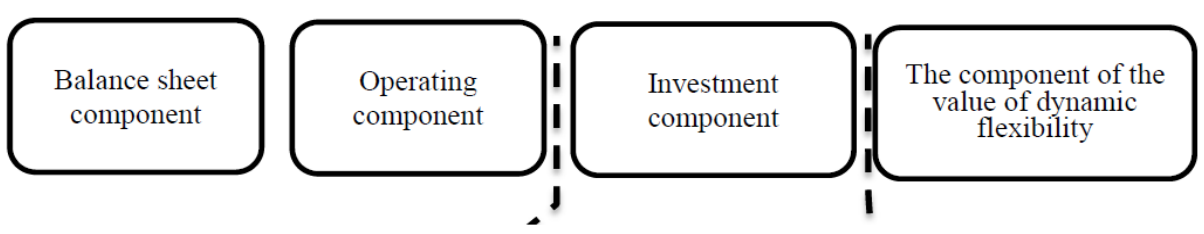

Levels of management of a trading enterprise

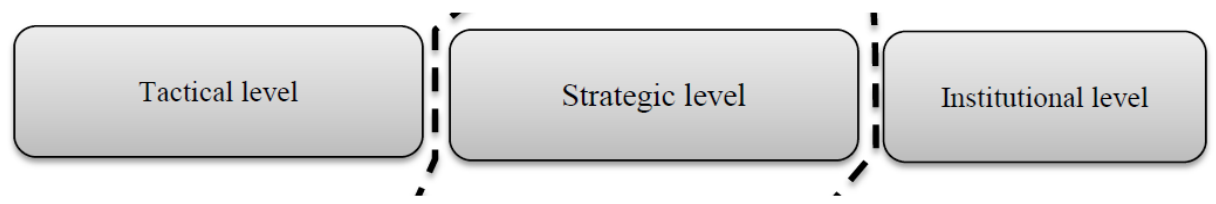

Forms of activity of a trading enterprise

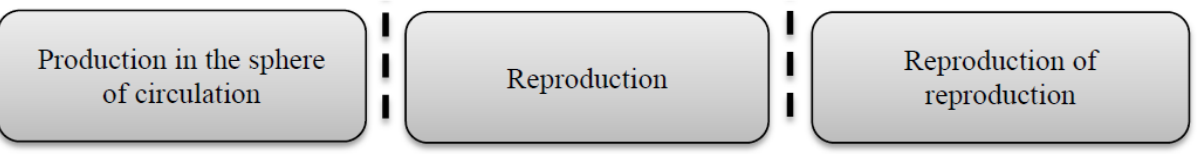

Fig. 2. Interrelation of the fundamental value model of a trading enterprise with levels of management and forms of activity.

Secondly, the introduction of such a classification allows us to choose approaches and methods for estimating the elements of fundamental value reasonably, based on the leading processes of its creation at one level or another.

Thirdly, depending on the level of value, the time horizon of planning also differs. The larger the horizon of planning and forecasting, the higher the variability of valuation and cost, which must also be taken into account when developing enterprise development plans.

It should also be noted that only the offered hierarchical four-level model of fundamental value, considering the enterprise through the prism of mechanisms for creating economic profit (added value), allows us to identify the levels of fundamental value that reflect the development of the enterprise.

\section{Conclusion}

The development of effective management systems for the development of trade enterprises at the current stage requires a revision of the approaches to determining the nature of activities and building target indicators based on the value approach. The key element in the realization of the value approach as a conceptual basis of management is the economic content of the cost indicators, based on which the system of development management criteria is built.

The offered four-level model of fundamental value in order to ensure sustainable development allows you to build a detailed system of performance indicators, reflecting all levels of creating a fundamental value. This allows managers to more closely control the processes of the enterprise from the point of view of solving the main economic task increasing the value of a trading enterprise, and making well-founded management decisions.

\section{References}

1. V. Berzakova, Company Globalization and its Socio-Economic Consequences, 15th International scientific conference proceedings, 27-32 (2015) 
2. A. Bolsinger, M. Bringing, Information systems and e-business management 13, 355398 (2015)

3. T. Copeland, T. Koller, J. Murrin, Valuation: Measuring and Managing the Value of Companies (McKinsey \& Company, Inc. New York, 1996)

4. B. Christophers, Dialogues in Human Geography 5(2), 183-200 (2015)

5. A. Rappaport, Journal of Business Strategyn 2, 14-28 (1986)

6. J.A. Ohlson, Contemporary Accounting Research 11(2), 661-687 (1995)

7. J. Stern, G. Stewart, D. Chew, Journal of Applied Corporate Finance 8(2), 32-46 (1995) DOI: $10.1111 / \mathrm{j} .1745-6622.1995 . t b 00285 . \mathrm{x}$

8. G.B. Stewart, The Quest for Value: A Guide for Senior Managers (Harper Business, New York, 1991)

9. N.I. Vinogradova, The effectiveness of retail businesses and ways to increase it: Monograph (OOO Teacher, Kursk, 2013)

10. M.V. Kudina, Theory of company value (ID FORUM: INFRA-M, 2010)

11. O.A. Nikolaevskaya, Valuation of the effectiveness of company management: Monograph (Publishing House "BIBLIO-GLOBUS", 2013)

12. T.V. Teplova, Investment levers to maximize the value of the company. Practice of Russian enterprises (Vershina, 2008)

13. On the approval of the federal standard of assessment "General concepts of assessment, approaches to evaluation and requirements for evaluation (FSO No. 1). Order of the Ministry of Economic Development of Russia of July 20, 2007 No. 256

14. On the approval of the federal standard of evaluation "Purpose of evaluation and types of value (FSO No. 2.) Order of the Ministry of Economic Development of Russia of July 20, 2007 No. 255

15. International Valuation Standards Committee. International standards for the assessment of IES $1-4$, http://www.ocenchik.ru/docs/468.html

16. Ivashkovskaya I.V. Modeling the value of the company. Strategic responsibility of the board of directors. M.: INFRA-M. 430p. (2009).

17. A. Damodaran, Investment valuation. Tools and techniques for assessing any assets (Alpina Business Books, Moscow, 2004)

18. O. Chernozub, Life after the crisis. A cost approach to managing a private company (Alpina Pablisher, Moscow, 2009)

19. V.G. Kogdenko, Management of the company's value. Value-oriented management (Unity-Dana, 2012)

20. A.O. Blinov, O.A. Nikolaevskaya, Corporate Governance and Venture Investment of the Syktyvkar State University 2, 113-126 (2014)

21. O.E. Pirogova, Economics and Management 5, 49-55 (2015)

22. O.E. Pirogova, Izvestiya of South-West State University 3, 69-75 (2013) 